\title{
Training of improving Arabic learning ability through the singing method in TK Paud R.A. Madrasah Hamdariyah in Medan Tembung District
}

\author{
Khairina Nasution ${ }^{1 *}$, Husnan Lubis ${ }^{1}$, Pujiati ${ }^{1}$, Takari $^{1}$ \\ ${ }^{1}$ Fakulty of Cultural Studies Universitas Sumatera Utara, Medan, Indonesia \\ *Email: khairina.nasution@usu.ac.id
}

\begin{abstract}
The community service that was carried out in TK PAUD R.A. Madrasah Hamdaniyah aims to improve the ability to learn Arabic through singing methods. The implementation of this service also includes improving the community's value system from the point of education. Arabic subjects have been taught in this kindergarten but the learning activities are not running optimally because the teacher still teaches Arabic using conventional methods. Another problem was found in the absence of media used to sing so that children quickly feel bored and bored when learning Arabic. To overcome this problem, the community service team at USU's Fakulty of Cultural Studies community will provide a solution to the problems found by replacing conventional methods with singing when teaching Arabic vocabulary. The method used in this service is the singing method and is supported by lecture, discussion, simulation and demonstration methods. Then the songs were sung by two students who participated in the service and were taught to kindergarten PAUD R.A. Madrasah Hamdaniyah. After dedication to kindergarten PAUD R.A. Madrasah Hamdaniyah results are very satisfying. Kindergarten children PAUD R.A. Madrasah Hamdaniyah does not feel afraid, ashamed and insecure anymore to actively participate in class. They began to dare to sing in front of the class and could answer the questions given.
\end{abstract}

Keyword: singing method, arabic, madrasah hamdaniyah, capacity building

\begin{abstract}
Abstrak
Pengabdian masyarakat yang dilaksanakan di TK PAUD R.A. Madrasah Hamdaniyah ini bertujuan untuk meningkatkan kemampuan belajar bahasa Arab melalui metode bernyanyi. Pelaksanaan pengabdian ini juga termasuk kepada perbaikan tata nilai masyarakat dari sudut pendidikan. Mata pelajaran bahasa Arab telah diajarkan di TK ini namun kegiatan pembelajarannya tidak berjalan maksimal karena guru masih mengajar bahasa Arab dengan menggunakan metode konvensional. Permasalahan lain yang ditemukan tidak adanya media yang digunakan untuk bernyanyi sehingga anak-anak cepat merasa jenuh dan bosan sewaktu belajar bahasa Arab. Untuk mengatasi permasalahan ini tim pengabdian pada masyarakat FIB USU akan memberi solusi terhadap permasalahan yang ditemukan dengan cara mengganti metode konvensional dengan metode bernyanyi sewaktu mengajarkan kosa kata bahasa Arab. Metode yang digunakan dalam kegiatan pengabdian ini adalah metode bernyanyi dan didukung oleh metode ceramah, diskusi, simulasi, dan demonstrasi. Selanjutnya lagu-lagu tersebut dinyanyikan oleh dua orang mahasiswa yang ikut serta dalam pengabdian dan diajarkan kepada anak TK PAUD R.A. Madrasah Hamdaniyah. Setelah dilakukan pengabdian kepada anak TK PAUD R.A. Madrasah Hamdaniyah hasilnya sangat memuaskan. Anak- anak TK PAUD R.A. Madrasah Hamdaniyah tidak merasa takut, malu dan minder lagi untuk berpatisipasi aktif di kelas. Mereka mulai berani bernyanyi di depan kelas dan bisa menjawab pertanyaan-pertanyaan yang diberikan.
\end{abstract}

Kata Kunci: Metode bernyanyi, bahasa Arab, Madrasah Hamdaniyah, Peningkatan Kemampuan 
Khairina et.al Training of improving Arabic

\section{PENDAHULUAN}

Pelajaran bahasa Arab sebagai bahasa asing sangat baik diperkenalkan sejak dini agar anak-anak nantinya dapat dan mampu memahami makna ajaran Islam dan dapat membawa dampak penting di dalam kehidupan mereka. Pengenalan terhadap bahasa Arab sejak awal didasari oleh suatu konsep paedagogis bahwa semakin dini usia seseorang diperkenalkan dengan bahasa target semakin cepat dan semakin bagus penguasaan dan pemerolehan anak terhadap bahasa yang dipelajarinya dalam hal ini bahasa Arab sebagai dasar untuk mempelajari Al-Quran. Tingkat penguasaan terhadap bahasa Arab yang diberikan sejak dini tidak akan maksimal apabila pendekatan ataupun metode pengajaran yang diberikan tidak tepat. Oleh sebab itu sangat diperlukan pemilihan kepada suatu metode pengajaran untuk mencapai tujuan yang telah ditentukan dan direncanakan.

TK PAUD Raudatul Atfal (RA) Madrasah Hamdaniyah adalah suatu lembaga yang bergerak di bidang agama Islam. Mata pelajaran bahasa Arab diberikan mulai dari tingkat awal sampai tingkat akhir. TK PAUD ini terletak di Jalan Tangkul 2, kelurahan Indra Kasih kecamatan Medan Tembung lebih kurang $30 \mathrm{~km}$ dari Universitas Sumatera Utara. TK ini didirikan pada tahun 2002. Pada tahun 2018 TK ini memiliki siswa yang berjumlah 38 orang dan gurunya berjumlah lima orang yang berasal dari Fakultas Agama Islam (FAI) dan jurusan Bahasa Indonesia. Guru-gurunya tidak berasal dari PG PAUD (Pendidikan Guru PAUD). TK PAUD R.A Madrasah Hamdaniyah ini termasuk kepada masyarakat yang tidak produktif secara ekonomi dan kebanyakan anak-anak yang sekolah di TK ini berasal dari keluarga yang kurang mampu seperti buruh dan penarik becak. Pembayaran honor guru juga sering tertunda.

TK PAUD ini memiliki visi mendidik siswanya menjadi siswa yang beriman, Islami, berakhlak, shaleh, cerdas, dan berprestasi. Mata pelajaran bahasa Arab telah diajarkan di TK ini namun kegiatan pembelajarannya tidak berjalan maksimal. Guru-guru yang mengajar bahasa Arab masih menggunakan metode konvensional dengan menggunakan buku teks (text-oriented) dengan menekankan pada penghafalan kosa kata saja sehingga membuat anak-anak TK cepat merasa jenuh dan bosan apalagi bagi anak-anak yang baru mengenal bahasa Arab. Permasalahan lain yang ditemukan di TK ini adalah tidak adanya alat (media) untuk bernyanyi yang bisa digunakan untuk melakukan praktek bernyanyi bersama-sama sehingga suasana belajar bahasa Arab semakin menarik dan menyenangkan.

Selain itu ruangan belajarnya terlalu sempit untuk siswa yang berjumlah 38 orang. Oleh sebab itu sangat dibutuhkan guru yang memiliki kemampuan khusus (bernyanyi) untuk mengelola kelas yaitu dengan metode bernyanyi dan media untuk bernyanyi. Metode belajar bahasa Arab dengan bernyanyi dapat menyenangkan anak dan membuat suasana nyaman sehingga anak-anak merasa tertarik dan lebih aktif untuk mengikuti pelajaran bahasa Arab.

Metode ini memberi warna baru dalam pembelajaran bahasa Arab, melalui bernyanyi anak dapat mengekspresikan segala pikiran dan isi hatinya. Lagu juga dapat menguatkan daya ingat karena melalui sesuatu yang menarik dan menyenangkan akan lebih mudah diingat dalam pikiran. Dilakukannya metode bernyanyi ini karena kebanyakan anak-anak pada tingkat awal sangat meyukai nyanyian dan anak dapat lebih mudah menghafal kosa kata bahasa Arab melalui nyanyian-nyanyian bahasa Arab yang diberikan setiap harinya.

Metode berasal dari bahasa Yunani methodos yang berasal dari kata meta berarti 'melalui' dan hodosberarti 'jalan', dan metode adalah jalan yang harus dilalui, cara melakukan sesuatu atau prosedur (Sankaji:2012). Bernyanyi adalah salah satu aktifitas yang sangat digemari sebagian besar masyarakat terutama untuk kalangan anak-anak (Yusriana:2012). Jadi metode bernyanyi adalah suatu cara untuk mencapai suatu tujuan dalam pembelajaran dengan cara yang menyenangkan yaitu dengan bernyanyi.

Berdasarkan latar belakang yang dipaparkan di atas maka permasalahan dalam pengabdian ini berkaitan dengan (1) metode pelatihan belajar bahasa Arab Madrasah Hamdaniyah dan (2) 
Khairina et.al Training of improving Arabic

Peningkatan kemampuan belajar bahasa Arab melalui metode bernyanyi di TK Paud R.A. Madrasah Hamdaniyah. Adapun kegiatan pengabdian ini bertujuan:

1. Memberikan pelatihan metode belajar bahasa Arab dengan metode bernyanyi di TK Paud R.A. Madrasah Hamdaniyah

2. Mengetahui peningkatan kemampuan belajar bahasa Arab melalui metode bernyanyi di TK Paud R.A. Madrasah Hamdaniyah.

\section{METODE PELAKSANAAN}

Pelatihan peningkatan kemampuan belajar bahasa Arab melalui metode bernyanyi yang dilaksanakan pada hari Sabtu tanggal 27 Juli 2019 di TK. Paud R.A. Madrasah Hamdaniyah juga menggunakan metode lainnya seperti metode ceramah, tanya jawab, simulasi dan demonstrasi. Langkah-langkah yang dilakukan dalam pengabdian ini adalah sebagai berikut:

1. Pertama-tama anak-anak diberi materi nyanyian yang berkaitan dengan pancaindra dan fungsinya, selamat ulang tahun dan macam-macam warna. Kemudian anak-anak diajak untuk memahami materi tersebut.

2. Tim pengabdian dibantu oleh mahasiswa mulai menyanyikan lagu tentang panca indera, selamat ulangtahun, dan macam-macam warna diikuti oleh anak-anak.

3. Tim pengabdian dan anak-anak mulai benyanyi bersama-sama

4. Selanjutnya anak-anak diminta bernyanyi di depan kelas satu persatu

5. Tim pengabdian memberikan penguatan kepada anak-anak yang dianggap mampu dan feedback.

Kegiatan ini dilakukan sebanyak dua kali sehingga hasilnya bisa optimal.

\section{HASIL DAN PEMBAHASAN}

Belajar bahasa Arab dengan metode bernyanyi membuat anak-anak lebih cepat mengerti, menguasai dan mempraktekkan mutu materi ajar yang disampaikan karena belajar sampai bernyanyi merupakan suatu metode yang sangat disukai anak-anak. Pada awal kegiatan tim pengabdian membuat tanya jawab yang sederhana tentang judul-judul lagu yang akan dinyanyikan pada proses pembelajaran. Kemudian anak-anak diberi materi kosa kata bahasa Arab yang berkaitan dengan panca indera, selamat ulangtahun dan macam-macam warna. Selanjutnya tim pengabdian mulai menyanyikan lagulagu tersebut sambil memperlihatkan videonya kepada anak-anak. Tim pengabdian mengulang beberapa kali kosakata-kosakata yang terdapat dalam nyanyian dan memperlambat ucapannya serta mengulang kembali kosakata tersebut satu persatu agar lebih mudah dimengerti.

Tim pengabdian pada masyarakat bernyanyi bersama anak-anak pada tahap berikutnya. Selanjutnya anak-anak diminta menyanyikan lagu bersama-sama tanpa tim pengabdian. Akhirnya tim pengabdian beserta anak-anak memeragakan isi nyanyian dengan gerakan sederhana untuk merefleksikan kegiatan pembelajaran bahasa Arab. Kemudian tim pengabdian meminta sebagian anakanak menyanyikan lagu seorang demi seorang di depan kelas dan meminta anak-anak untuk menjawab pertanyaan yang diberikan kepadanya bagi anak-anak yang masih kurang dan penguasaan lagunya diadakan pendekatan dengan cara menyuruhnya menjadi pemimpin bernyanyi dan tim pengabdian mendampinginya saat bernyanyi bersama. Kemudian ditanyakan ketidakjelasan syair lagu yang belum dipahami anak-anak.

Pelaksanaan pengabdian tahap 2 dilakukan pada tanggal 20 Agustus 2019. Pada pertemuan ini anak-anak tidak diperkenalkan lagi dengan nyanyian bahasa Arab yang baru, tapi mereka diajak kembali untuk mengulangi nyanyian-nyanyian yang pernah diajarkan pada pertemuan pertama. Tim 
pengabdian pada masyarakat bernyanyi lebih dahulu kemudian diikuti oleh anak-anak sebanyak tiga kali berulang-ulang sehingga anak-anak sudah mengingat kembali lagu tersebut dan dapat menyanyikannya. Kemudian anak-anak ditanyai tentang kosakata yang terdapat di dalam lagu-lagu tersebut.

Akhirnya anak-anak TK Paud R.A. Madrasah Hamdaniyah dapat menjawab semua pertanyaan yang diberikan kepada mereka. Sebagai evaluasi anak-anak disuruh menyanyikan lagu tersebut ke depan kelas satu persatu. Untuk memotivasi anak-anak agar mau bernyanyi di depan kelas tim pengabdian memberikan hadiah berupa satu set alat tulis kepada anak-anak. Semua anak-anak berlomba-lomba untuk bernyanyi di depan kelas satu persatu.

Hasil yang diperoleh setelah melakukan kegiatan pembelajaran bahasa Arab dengan metode bernyanyi sangat memuaskan. Penggunaan metode bernyanyi dapat meningkatkan motivasi belajar anak-anak di TK Paud R.A. Madrasah Hamdaniyah. Pada pertemuan ini juga tim pengbdian memberikan softcopy lagu berbahasa Arab ke TK Paud R.A. Madrasah Hamdaniyah dan sebuah infokus agar guru-guru di TK Paud R.A. Madrasah Hamdaniyah tersebut dapat meneruskan kegiatan bahasa Arab dengan menggunakan metode bernyanyi secara visualisasi. Kegiatan belajar bahasa Arab dengan cara seperti ini diharapkan dapat menyenangkan dan memotivasi anak-anak TK Paud R.A. Madrasah Hamdaniyah untuk belajar bahasa Arab melalui nyanyian.

\section{KESIMPULAN}

Pelaksanaan pengabdian pada masyarakat yang dilakukan di TK Paud R.A. Madrasah Hamdaniyah dapat meningkatkan minat anak-anak untuk belajar bahasa Arab karena kosakata bahasa Arab yang diajarkan dikemas dalam bentuk nyanyian yang menyenangkan. Isi nyanyian yang pendek dan bahasa yang digunakan secara sederhana membuat anak-anak mudah mencerna dan mengucapkan kosakata Arab yang diucapkan. Dengan demikian metode bernyanyi adalah metode yang sesuai apabila diterapkan pada anak usia pra sekolah seperti TK Paud R.A. Madrasah Hamdaniyah karena metode bernyanyi merupakan kegiatan yang disukai anak-anak.

\section{UCAPAN TERIMA KASIH}

Kegiatan pengabdian pada masyarakat yang dilaksanakan di TK Paud R.A. Madrasah Hamdaniyah kecamatan Medan Tembung telah terlaksana dengan baik dan kegiatan ini dapat dianggap berhasil karena anak-anak TK Paud R.A. Madrasah Hamdaniyah sudah dapat mengerti, menguasai dan menyanyikan lagu-lagu berbahasa Arab yang diberikan oleh tim pengabdian pada masyarakat dari FIB USU. Oleh sebab itu tim pengabdian pada masyarakat mengucapkan terima kasih kepada pihak LPPM USU yang telah memberikan dana kepada pengabdian ini. Terima kasih juga kepada pihak mitra yang telah koopratif di dalam pelaksanaan pengabdian ini.

\section{DAFTAR PUSTAKA}

Bahri, Syaiful. 2006. Strategi Belajar Mengajar. Jakarta: Rineka Cipta

Fadilah, Muhammad. 2012. Desain Pembelajaran PAUD. Yogyakarta: Ar-Razz Media.

Patmonodewo, Soemiarti. 2003. Pendidikan Anak Pra Sekolah. Jakarta: Runika Cipta

Sujdana, Nana. 2010. Penilaian Hasil Proses Belajar Mengajar.Bandung: Remaja Rosdakarya. 
Khairina et.al Training of improving Arabic

Wahab, Muhbib Abdul. 2008. Epistemologi \& Metodologi Pembelajaran Bahasa Arab. Jakarta: Lembaga Penelitian UIN Syarif Hidayatullah.

Widyanti, Sri. 2014. Penerapan Metode Dengan Media Audiovisual Untuk Meningkatkan Keterampilan Berbahasa Pada Anak Usia Dini Di Kelompok B4 Tk Kartika Ii-20 Curup. Bengkulu: Universita Bengkulu.

Wiranata, Putra, dkk. 2004. StrategiBelajar Mengajar. Jakarta: Universitas Terbuka.

Yusriana, Ajeng. 2012. Kiat-Kiat Menjadi Guru PAUD yang disukai Anak-Anak. Yogyakarta: Diva Press. 